\title{
Benomyl-resistant Beauveria bassiana (Hypocreales: Clavicipitaceae) mutants induced by ion beams
}

\author{
Yuyun Fitriana $\cdot$ Shinobu Shinohara $\cdot$ Katsuya Satoh $\cdot$ \\ Issay Narumi · Tsutomu Saito
}

Received: 26 September 2014 / Accepted: 25 November 2014 / Published online: 18 December 2014

(C) The Japanese Society of Applied Entomology and Zoology 2014

\begin{abstract}
Fungicides targeted at phytopathogens can be harmful to entomopathogenic fungi. The purpose of this study was to use ion-beam irradiation technology to produce benomyl-resistant mutants of the entomopathogenic fungus Beauveria bassiana (Bals.-Criv.) Vuill. After irradiation of conidia at $150 \mathrm{~Gy}$, two mutant isolates, BB22 and BB24, were selected on media containing the fungicide. In an assay of vegetative growth, BB22 and BB24 were over 500 and 800 times more tolerant to benomyl, respectively, compared with the wild isolate. However, in an assay of conidial germination, neither mutant had increased tolerance compared with the wild isolate. Both mutant isolates also had increased tolerance to thiophanate-methyl during vegetative growth, but reduced tolerance to diethofencarb. A mutation was found at position 198 of the $\beta$-tubulin gene in the mutant isolates, with a substitution of glutamate for alanine (E198A). Ion beams have great potential as a tool to improve the traits of entomopathogenic fungi such as increasing tolerance to fungicides. Fungicide-resistant mutants produced in this way could be useful agents for biological control within IPM programmes where fungicides are also used.
\end{abstract}

Y. Fitriana $\cdot$ S. Shinohara $\cdot$ T. Saito $(\bowtie)$

Faculty of Agriculture, Shizuoka University, Shizuoka 422-8529, Japan

e-mail: atsaito@ipc.shizuoka.ac.jp

K. Satoh $\cdot$ I. Narumi

Quantum Beam Science Directorate, Japan Atomic Energy

Agency, Gunma 370-1292, Japan

Present Address:

I. Narumi

Faculty of Life Sciences, Toyo University, Gunma 374-0193,

Japan
Keywords Fungicide compatibility $\cdot 50 \%$ Effective concentration · Integrated pest management $\cdot \beta$-Tubulin . Cross tolerance

\section{Introduction}

Entomopathogenic fungi infect their hosts by direct penetration through the integument causing fatal infections (Inglis et al. 2001); many species have been commercialized as biological control agents of insect pests (Copping 2009). However, they can be negatively affected by fungicides (Clark et al. 1982; D'Alessandro et al. 2011; Saito 1984), with the result that their biological control potential can be reduced if both products are used together in IPM systems for insect pests.

To overcome this problem of compatibility, researchers have been developing fungicide-resistant mutants of entomopathogenic fungi through gene transformation (Valadares-Inglis and Inglis 1997), UV light (Kim et al. 2005) and the mutagen $\mathrm{NaNO}_{2}$ (Zou et al. 2006). However, ion-beam irradiation, which causes a higher mutation frequency and broader mutation spectrum and creates point mutations in genes, may prove even more useful (Tanaka et al. 2010; Toyoshima et al. 2012). For example, ion beams have been used to produce mutants of Cordyceps militaris (L.) Link with enhanced production of the medical compound cordycepin (Das et al. 2008). To the best of our knowledge, there has only been one other report of the use of ion beams on an entomopathogenic fungus, Isaria fumosorosea Wize, to enhance the tolerance to benomyl, one of the most commonly used fungicides in crop protection (Shinohara et al. 2013). However, this technology could be applied to other entomopathogenic fungi, such as Beauveria bassiana (Bals.-Criv.) Vuill., which is also 
widely used in biological control of insect pests (Copping 2009; Inglis et al. 2001).

The purpose of this study was to produce $B$. bassiana mutants that are resistant to benomyl using ion beams. The resulting benomyl-resistant mutants were then evaluated for enhanced tolerance to a range of commonly used fungicides from other chemical groups and for any mutations in the $\beta$-tubulin gene; replacement of amino acids in this gene is closely associated with resistance to benzimidazole fungicides, such as benomyl and carbendazim, in B. bassiana (Zou et al. 2006) and plant-pathogenic fungi (e.g., Fujimura et al. 1992; Hollomon et al. 1998; Ma et al. 2003).

\section{Materials and methods}

Preparation of fungal material

A stock culture of Beauveria bassiana isolate B1026, which is a single-spore strain collected from an unidentified beetle larva in 1991 in Shizuoka, Japan, was used as the wild type and had been positively identified as B. bassiana from the 18S rDNA gene partial sequence (DDBJ/EMBL/ GenBank accession no. LC008545). For experiments, it was subcultured onto Sabouraud dextrose agar (SDA, Difco BD Bioscience, USA) in 90-mm-diameter petri dishes and incubated at $23 \pm 1{ }^{\circ} \mathrm{C}$ for 3 weeks in darkness. The SDA medium was composed of $40 \mathrm{~g}$ dextrose, $10 \mathrm{~g}$ peptone and $15 \mathrm{~g}$ agar in $1,000 \mathrm{ml}$ distilled water (Goettel and Inglis 1997). Stock conidial suspensions were prepared by scraping the mycelium from plate cultures into sterile $0.1 \%$ Tween 80 , agitating with a vortex mixer and then filtering through sterile cloth $(0.2 \mathrm{~mm}$ mesh size). The concentration of conidia in the stock suspension was determined using a Thoma hemocytometer and adjusted to the concentration required for each experiment by the addition of sterile $0.1 \%$ Tween 80 .

\section{Fungicides}

Seven commercial fungicides were used in this study (Table 1). They are all commonly used fungicides, and each came from a different chemical group, except for benomyl and thiophanate-methyl, which were both benzimidazoles. Each was added to autoclaved SDA once it had cooled to below $50{ }^{\circ} \mathrm{C}$ and mixed before pouring into sterile $90-\mathrm{mm}$ diameter petri dishes $(30 \mathrm{ml}$ per dish). The concentration of each fungicide was represented as the active ingredient throughout this study.

\section{Determining effective irradiation doses}

Fifty $\mu \mathrm{l}$ of conidial suspension $\left(2 \times 10^{3}\right.$ conidia $\left.\mathrm{ml}^{-1}\right)$ from the wild isolate was placed in a petri dish $(60 \mathrm{~mm}$ diameter) containing $10 \mathrm{ml}$ of SDA and spread evenly across the agar surface. Dishes were covered with sterile polyimide film (Kapton 30EN, Du Pont-Toray, Japan) and irradiated at different doses $(0,50,100,150,200,250,300,350$ and $400 \mathrm{~Gy})$ with carbon ion beams $\left({ }^{12} \mathrm{C}^{5+}, 121.8 \mathrm{keV} \mu \mathrm{m}^{-1}\right.$, approximately $0.1-1 \mathrm{~Gy} \mathrm{~s}^{-1}$ ) accelerated by an azimuthally varying field cyclotron at the Takasaki Ion Accelerators for Advanced Radiation Application site (Gunma, Japan). Five replicate dishes were used for each dose. The irradiated dishes, and the conidia they contained, were incubated at $23 \pm 1{ }^{\circ} \mathrm{C}$ in darkness for 3 days. Survival rates were determined by comparing the numbers of colonies per dish (each assumed to originate from one conidium) that grew at each dose and used to select the most appropriate doses to produce mutants.

\section{Selection of benomyl-resistant mutants}

Conidia from the wild isolate were extracted from 3-ml samples of the conidial suspension $\left(1.0 \times 10^{8}\right.$ conidia $\mathrm{ml}^{-1}$ ) onto sterile cellulose membrane filters ( $47 \mathrm{~mm}$ diameter, $0.45 \mu \mathrm{m}$ pore size; Millipore, Merck Millipore, Germany) using filtration equipment and washed twice with $10 \mathrm{ml}$ of sterile $0.1 \%$ Tween 80 . The filters were individually placed in $60-\mathrm{mm}$ petri dishes and covered with sterile polyimide film. The petri dishes were then irradiated at the selected doses to produce mutants (see below). Three replicate filters were used for each dose. Each filter was then transferred to a vial containing $3 \mathrm{ml}$ Sabouraud dextrose broth (Difco BD Bioscience, USA) and agitated with a
Table 1 Fungicides used in this study

\footnotetext{
${ }^{a}$ Wettable powder

b Suspension concentrate

c Emulsifiable concentrate
}

\begin{tabular}{lll}
\hline Common name (\% ai and formulation) & Chemical group & Production \\
\hline Benomyl $\left(50 \% \mathrm{WP}^{\mathrm{a}}\right)$ & Benzimidazole & Sumitomo Chemical, Japan \\
Thiophanate-methyl $(70 \% \mathrm{WP})$ & Benzimidazole & Nippon Soda, Japan \\
Iprodione $(50 \% \mathrm{WP})$ & Dicarboximide & Nippon Soda, Japan \\
Chlorothalonil $\left(40 \% \mathrm{SC}^{\mathrm{b}}\right)$ & Phthalonitrile & Kumiai Chemical, Japan \\
Myclobutanil $\left(25 \% \mathrm{EC}^{\mathrm{c}}\right)$ & Triazole & Dow Chemical, Japan \\
Triflumizole $(15 \% \mathrm{EC})$ & Imidazole & Ishihara Sangyo Kaisha, Japan \\
Diethofencarb $(25 \% \mathrm{WP})$ & $N$-phenylcarbamate & Sumitomo Chemical, Japan \\
\hline
\end{tabular}


sterile glass rod to detach the conidia. The conidial suspensions were incubated at $20 \pm 1{ }^{\circ} \mathrm{C}$ in darkness overnight to remove mutations that were unstable through cell division. Then $200 \mu \mathrm{l}$ of each suspension was spread onto $30 \mathrm{ml}$ SDA containing benomyl $\left(1,000 \mathrm{mg} \mathrm{l}^{-1}\right)$ in a $90-\mathrm{mm}$ petri dish and incubated at $23 \pm 1{ }^{\circ} \mathrm{C}$ in darkness. Six replicate dishes were made in this way from the contents of each vial. After incubation for 2 weeks, well-grown colonies were assumed to be benomyl-resistant and were isolated onto fresh SDA; colonies that differed in shape and color from the wild isolate were excluded.

Benomyl resistance during vegetative growth

Mycelial plugs (4 $\mathrm{mm}$ diameter) from each isolate were excised from the margins of colonies growing on SDA in 90-mm-diameter petri dishes (4-5-day-old cultures incubated at $25 \pm 1{ }^{\circ} \mathrm{C}$ in darkness), and each plug was placed upside down at the center of a 90-mm-diameter petri dish containing $30 \mathrm{ml}$ SDA to which benomyl had been added $\left(0,0.3,1,3\right.$ or $10 \mathrm{mg} \mathrm{l}^{-1}$ for the wild isolate; $0,30,100$, $300,1,000$ or $3,000 \mathrm{mg} \mathrm{l}^{-1}$ for the mutants). Nine replicate pairs of treatment and control dishes were prepared for each dose. After incubation at $25 \pm 1{ }^{\circ} \mathrm{C}$ in darkness for 10 days, the colony diameter was estimated from two perpendicular measurements across each colony, excluding $4 \mathrm{~mm}$ to account for the diameter of the inoculation plug, and then the mean colony diameter was determined for each replicate. Percent inhibition values for each replicate were calculated using the formula given below.

Percent inhibition $=(a-b) / a \times 100$

In this formula, $a$ and $b$ were the colony diameters ( $\mathrm{mm}$ ) of the control and the fungicide dishes from each pair, respectively. The nine data points on percent inhibition (one from each replicate treatment and control pair of dishes) for each dose were used to estimate the $\mathrm{EC}_{50}$ value $(50 \%$ effective concentration) of each isolate by probit regression analysis against the logarithmic values of the fungicide doses (SPSS 2009). The tolerance ratio (TR) for each mutant was determined by dividing the $\mathrm{EC}_{50}$ value for each mutant isolate by that for the wild isolate.

Benomyl resistance during conidial germination

Three $20-\mu \mathrm{l}$ aliquots of conidial suspension $\left(1.0 \times 10^{6}\right.$ conidia $\mathrm{ml}^{-1}$ ) from mutant and wild isolates were each placed individually onto $30 \mathrm{ml}$ of SDA containing benomyl $\left(0,1,2.5,5,10,25,50\right.$ or $\left.100 \mathrm{mg} \mathrm{l}^{-1}\right)$ in 90 -mm-diameter petri dishes. In addition, aliquots were placed onto control plates that had been produced in the same way but without fungicide. Each aliquot was covered with a sterile glass coverslip $(18 \mathrm{~mm} \times 18 \mathrm{~mm})$. The dishes were incubated at
$25 \pm 1{ }^{\circ} \mathrm{C}$ in darkness for $16 \mathrm{~h}$. After the addition of lactophenol cotton blue, the percentage germination of approximately 100 conidia per aliquot was determined under a microscope (Axio Imager 2, Zeiss, Germany). Three replicate dishes were prepared for each dose. The mean percentage germination for three aliquots in each dish was corrected for mean percentage germination in the control (no fungicide) using Abbott's formula (Abbott 1925), and then the $\mathrm{EC}_{50}$ of each isolate was estimated as above, using all data from seven doses.

\section{Tolerance to other fungicides}

Tolerance of mutant and wild isolates to seven selected fungicides (Table 1) was estimated from colony diameters on SDA to which the fungicides had been added at recommended field application rates. The methods were as described previously for vegetative growth on agar containing benomyl; nine replicate pairs of treatment and control dishes were prepared for each dose. For each replicate colony, the vegetative growth ratio (GR) of each isolate was obtained using the following formula.

\section{Colony diameter on fungicide/colony diameter on control}

Tolerance to each fungicide was statistically compared using the GRs obtained for each isolate with ANOVA followed by Tukey's HSD tests (SPSS 2009).

\section{$\beta$-Tubulin sequences}

Mutant and wild isolates were each cultured on $25 \mathrm{ml}$ SDA at $20{ }^{\circ} \mathrm{C}$ in darkness for 3 days, and then a small amount of mycelium and conidia from each dish was scraped into a sterile tube for extraction of genomic DNA using a FastDNA Spin Kit (MP Biomedicals, UK). A partial $\beta$-tubulin sequence was amplified in a GeneAmp PCR System 9700 (Life Technologies, USA) using two specific primers: Beauveria_beta-tub-F and Beauveria_beta-tub-R (Table 2). PCR conditions were an initial $98{ }^{\circ} \mathrm{C}$ for $20 \mathrm{~s}$, 30 cycles of denaturation at $98{ }^{\circ} \mathrm{C}$ for $10 \mathrm{~s}$, primer annealing at $63{ }^{\circ} \mathrm{C}$ for $15 \mathrm{~s}$ and extension at $72{ }^{\circ} \mathrm{C}$ for $2 \mathrm{~min}$ followed by a final elongation at $72{ }^{\circ} \mathrm{C}$ for $5 \mathrm{~min}$. PCR was done in $50-\mu \mathrm{l}$ reaction volumes consisting of $10 \mu \mathrm{l}$ genomic DNA $\left(5 \mathrm{ng} \mathrm{ml}^{-1}\right), 5 \mu \mathrm{l} 10 \times$ ExTaq buffer, $4 \mu \mathrm{ldNTP}$ mixture, $0.25 \mu \mathrm{l}$ ExTaq DNA polymerase (TaKaRa Bio, Japan), $0.2 \mu$ of each primer $\left(50 \mu \mathrm{mol} \mathrm{l}^{-1}\right)$ (Sigma Genosys, Japan) and $30.35 \mu \mathrm{l}$ sterile distilled water. Using these primers produced an amplicon of 1,428 bp. The PCR products were run in $0.7 \%$ agarose gel made with TAE buffer ( $40 \mathrm{mmol} \mathrm{l}^{-1}$ Tris, $20 \mathrm{mmol} \mathrm{l}^{-1}$ sodium acetate, $1 \mathrm{mmol}^{-1}$ EDTA, $\mathrm{pH}$ 8.0) at $100 \mathrm{~V}$, stained with ethidium bromide $\left(0.5 \mu \mathrm{g} \mathrm{ml}^{-1}\right)$ and visualized under UV light. The targeted 
Table 2 Primers used in this study

\begin{tabular}{lll}
\hline Primer & Sequence $\left(5^{\prime}-3^{\prime}\right)$ & Use \\
\hline Beauveria_beta-tub-F & CAGTGCGGTAACCAAATCG & PCR and sequencing \\
Beauveria_beta-tub-R & CAAAGGCTCCTCGCCCTCAA & PCR and sequencing \\
Beauveria_beta-tub-F2 & CAGGGTTTCCAGATCACCC & Sequencing \\
Beauveria_beta-tub-R2 & CTTCATGGCAACCTTACCAC & Sequencing \\
Beauveria_beta-tub-F3 & GAGGACCAGATGCGTAATGTG & Sequencing \\
Beauveria_beta-tub-R3 & GAACAACGTCGAGGACCTG & Sequencing \\
\hline
\end{tabular}

bands were cut from the gels and the PCR product collected and purified using a MinElute PCR Purification Kit (Qiagen, Japan). Purified PCR products were sequenced in an ABI Prism 377 DNA Sequencer (Life Technologies). PCR for sequencing was done in $20 \mu \mathrm{l}$ reaction volumes containing $2 \mu \mathrm{l} \mathrm{PCR}$ product $\left(20 \mathrm{ng} \mu^{-1}\right), 8 \mu \mathrm{l}$ sterile distilled water, $4 \mu \mathrm{l} 5 \times$ sequencing buffer, $4 \mu \mathrm{l}$ of primers for $\beta$-tubulin $\left(0.8 \mu \mathrm{mol} \mathrm{l}^{-1}\right)$ (Table 2$)$ and $2 \mu \mathrm{l} \mathrm{BigDye} \mathrm{Termi-}$ nator v 3.1 (Life Technologies). PCR conditions were 25 cycles at $96{ }^{\circ} \mathrm{C}$ for $10 \mathrm{~s}, 50{ }^{\circ} \mathrm{C}$ for $5 \mathrm{~s}$ and $60{ }^{\circ} \mathrm{C}$ for $4 \mathrm{~min}$. The products were purified through Sephadex G-50 Superfine gel filtration medium (GE Healthcare, UK), dried at $75{ }^{\circ} \mathrm{C}$ for $45 \mathrm{~min}$ and dissolved in sequence-loading buffer (83\% formamide, $4.2 \mathrm{mmol}^{-1}$ EDTA, $8.3 \mathrm{mg} \mathrm{ml}^{-1}$ blue dextran). The $\beta$-tubulin sequences for the mutant isolates were compared with the sequence for the wild isolate in SeqMan Pro (DNASTAR, WI, USA) and GENETYXMAC (GENETYX, Japan) software packages. Multiple alignment of the deduced amino acid was employed using the CLUSTAL W programme (Thompson et al. 1994).

\section{Results and discussion}

To determine the most appropriate irradiation dose (in Gy, the unit of absorbed energy of ionizing radiation) for production of mutants, we examined the relationship between irradiation dose and conidial survival rate. In previous studies, the highest mutation frequency obtained by ionbeam irradiation was associated with survival rates of 1 to $10 \%$ in Saccharomyces cerevisiae Meyen ex E.C. Hansen (Matuo et al. 2006) and Aspergillus oryzae (Ahlburg) Cohn (Toyoshima et al. 2012). Based on this premise, we selected and used doses of 100,150, 200, 250, 300 and $350 \mathrm{~Gy}$; these doses had resulted in survival rates of between 0.2 and $36.8 \%$ in our wild isolate of B. bassiana (Table 3 ). We included 100 and 350 Gy even though these doses indicated survival rates outside of the desired 1 to $10 \%$ range, because we considered it was safer to have a wide range and ensure some mutants were produced in the experiments than to use a narrow range and potentially produce no mutants (Table 3 ). Of these doses, $150 \mathrm{~Gy}$ provided two large colonies on media containing benomyl $\left(1,000 \mathrm{mg} \mathrm{l}^{-1}\right)$
Table 3 Relationship between the ion-beam irradiation dose and conidial survival rate of the wild isolate of B. bassiana

\begin{tabular}{lll}
\hline Dose $($ Gy) & $\begin{array}{l}\text { No. of colonies per } \\
\text { petri dish }(\text { mean } \pm \text { SE) }\end{array}$ & $\begin{array}{l}\text { Survival } \\
\text { rate }(\%)^{\mathrm{a}}\end{array}$ \\
\hline 0 & $193.7 \pm 9.8$ & 100 \\
50 & $145.7 \pm 25.0$ & 75.2 \\
100 & $71.3 \pm 15.5$ & 36.8 \\
150 & $22.0 \pm 3.5$ & 11.4 \\
200 & $7.6 \pm 0.3$ & 3.9 \\
250 & $4.7 \pm 0.3$ & 2.4 \\
300 & $0.7 \pm 0.3$ & 0.4 \\
350 & $0.3 \pm 0.3$ & 0.2 \\
400 & 0 & 0 \\
\hline
\end{tabular}

a (Mean number of irradiated colonies/mean number of control colonies) $\times 100$

(Fig. 1), which were isolated as benomyl-resistant mutants and designated as BB22 and BB24. Conidia without irradiation produced no large colonies on the benomyl-amended media.

In the experiments to determine the $\mathrm{EC}_{50}$ for vegetative growth on media amended with benomyl, the wild and mutant isolates achieved colony diameters of $35-40 \mathrm{~mm}$ on the control plates without fungicide (in 90-mm-diameter petri dishes) after 10 days. The $\mathrm{EC}_{50}$ value of benomyl for vegetative growth was $0.99 \mathrm{mg}^{-1}$ for the wild isolate, $564 \mathrm{mg}^{-1}$ for BB22 and $828 \mathrm{mg} \mathrm{l}^{-1}$ for BB24; TR for the mutants was 570 and 836 , respectively (Table 4). Thus, irradiation with ion beams produced benomyl-resistant mutants, as evidenced by their mycelial growth. Such resistance has also been found previously for $\mathrm{NaNO}_{2}$ induced mutants that had a minimal inhibitory concentration (MIC) of $>1,000 \mathrm{mg}^{-1}$ for the benzimidazole fungicide, carbendazim (Zou et al. 2006). These levels of resistance may be sufficient to attenuate the serious effects of the commercial application rates $\left(250-500 \mathrm{mg}^{-1}\right)$ of these fungicides in the field.

In contrast, there was no significant difference in conidial germination between the wild isolate $\left(\mathrm{EC}_{50}: 10.2 \mathrm{mg} \mathrm{l}^{-1}\right)$ and mutant isolates $\left(\mathrm{EC}_{50}\right.$ and TR: $11.6 \mathrm{mg} \mathrm{l}^{-1}$ and 1.14 for BB22; $9.7 \mathrm{mg} \mathrm{l}^{-1}$ and 0.95 for BB24) (Table 4). Thus, 


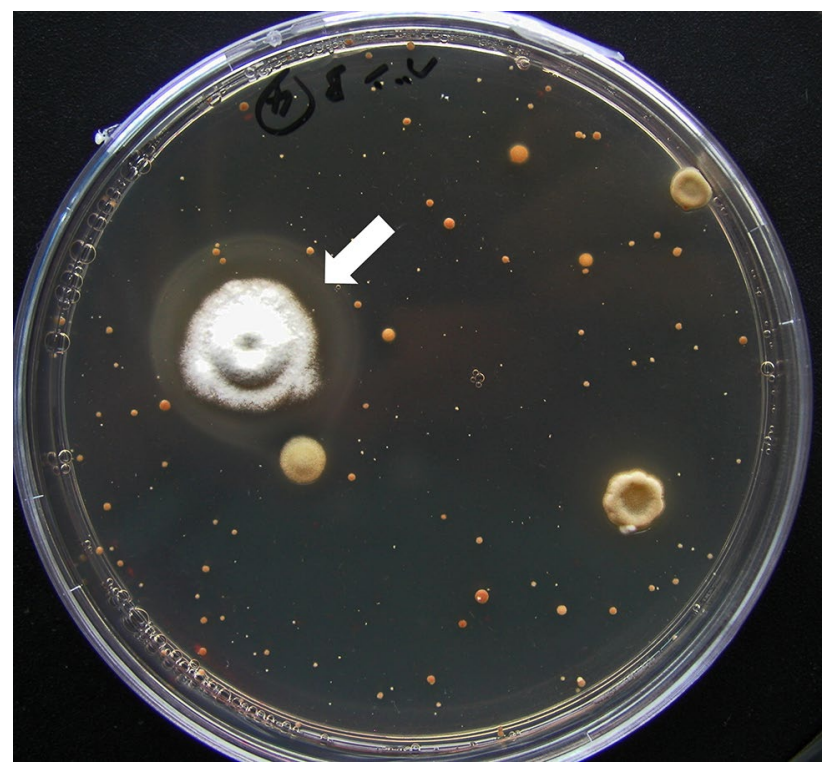

Fig. 1 A benomyl-resistant colony (arrow) derived from B. bassiana wild isolate conidia irradiated by ion beams (150 Gy) on SDA containing benomyl $\left(1,000 \mathrm{mg}^{-1}\right)$

B. bassiana mutants obtained in this study had resistance during vegetative growth (hyphal extension) but not during initial conidial germination. However, if the mutants are applied at least 1 day before application of benomyl in the field, they should still successfully control target insect pests, because most conidia germinate within $20 \mathrm{~h}$ at $25-32{ }^{\circ} \mathrm{C}$ and would be growing vegetatively by the time the fungicide was applied (James et al. 1998); infection occurs on the host surface by hyphal extension and penetration of the cuticle (Boucias and Pendland 1998), which would not be affected by the fungicide.

Tolerance of the wild isolate and mutants BB22 and BB24 to seven fungicides at recommended field application rates was compared using GRs. Overall, all isolates tested produced smaller colonies on media with fungicides incorporated than on control media, indicating that the wild isolate and mutant isolates were both negatively affected by these fungicides (Table 5). However, the extent of the effect was different between mutant isolates and the wild isolate. On media with benomyl, mutants BB22 and BB24 had significantly larger GRs ( 0.73 and 0.72 , respectively) than the wild isolate (GR: 0.12) $(p<0.05$, Tukey's HSD test) and were therefore more tolerant than the wild isolate. Both mutant isolates were also significantly more tolerant to thiophanate-methyl (GR: 0.99 and 0.87 , respectively) than the wild isolate (GR: 0.22) $(p<0.05$, Tukey's HSD test). This enhanced tolerance may result from cross-resistance between benzimidazole fungicides, such as benomyl and thiophanate-methyl, as seen in plant-pathogenic fungi

Table 4 Benomyl tolerance as measured by vegetative growth and conidial germination of the wild and mutant isolates of B. bassiana on SDA impregnated with benomyl

\begin{tabular}{|c|c|c|c|c|c|c|}
\hline \multirow[t]{2}{*}{ Isolate } & \multicolumn{3}{|c|}{ Vegetative growth } & \multicolumn{3}{|c|}{ Conidial germination } \\
\hline & $\mathrm{EC}_{50}\left(\mathrm{mg} \mathrm{l}^{-1}\right)$ & $95 \% \mathrm{CL}\left(\mathrm{mg} \mathrm{l}^{-1}\right)$ & $\mathrm{TR}^{\mathrm{a}}$ & $\mathrm{EC}_{50}\left(\mathrm{mg} \mathrm{l}^{-1}\right)$ & $95 \% \mathrm{CL}\left(\mathrm{mg} \mathrm{l}^{-1}\right)$ & TR \\
\hline Wild & 0.99 & $0.86-1.14$ & 1 & 10.2 & $7.6-13.9$ & 1 \\
\hline BB22 & 564 & $481-667$ & 570 & 11.6 & $9.0-14.9$ & 1.14 \\
\hline BB24 & 828 & $634-1137$ & 836 & 9.7 & $6.9-14.1$ & 0.95 \\
\hline
\end{tabular}

${ }^{\mathrm{a}} \mathrm{EC}_{50}$ value of mutant isolate/ $\mathrm{EC}_{50}$ value of wild isolate

Table 5 Colony diameters $(\mathrm{mm}$, mean $\pm \mathrm{SE})$, with growth ratios $\left(\mathrm{GR}^{\mathrm{a}}\right.$, mean $\left.\pm \mathrm{SE}\right)$ in parentheses, of the wild and mutant isolates of $B$. bassiana on SDA containing different fungicides, each at the recommended field application rate

\begin{tabular}{|c|c|c|c|c|c|c|c|c|}
\hline Isolate & $\begin{array}{l}\text { Benomyl } \\
\left(500 \mathrm{mg} \mathrm{l}^{-1}\right)\end{array}$ & $\begin{array}{l}\text { Thiophanate- } \\
\text { methyl } \\
\left(700 \mathrm{mg} \mathrm{l}^{-1}\right)\end{array}$ & $\begin{array}{l}\text { Iprodione } \\
\left(500 \mathrm{mg} \mathrm{l}^{-1}\right)\end{array}$ & $\begin{array}{l}\text { Chlorothalonil } \\
\left(400 \mathrm{mg} \mathrm{l}^{-1}\right)\end{array}$ & $\begin{array}{l}\text { Myclobu- } \\
\text { tanil } \\
\left(625 \mathrm{mg} \mathrm{l}^{-1}\right)\end{array}$ & $\begin{array}{l}\text { Triflumizole } \\
\left(150 \mathrm{mg}^{-1}\right)\end{array}$ & $\begin{array}{l}\text { Diethofencarb } \\
\left(250 \mathrm{mg} \mathrm{l}^{-1}\right)\end{array}$ & $\begin{array}{l}\text { Control (no } \\
\text { fungicide) }\end{array}$ \\
\hline Vild & $\begin{array}{l}4.8 \pm 0.6 \\
\quad(0.11 \pm 0.01) \mathrm{a}\end{array}$ & $\begin{array}{l}9.4 \pm 0.4 \\
\quad(0.22 \pm 0.01) \mathrm{a}\end{array}$ & $\begin{array}{l}13.8 \pm 1.5 \\
\quad(0.32 \pm 0.03) \mathrm{a}\end{array}$ & $\begin{array}{l}37.8 \pm 0.6 \\
\quad(0.88 \pm 0.03) \mathrm{a}\end{array}$ & 0 & $\begin{array}{l}10.8 \pm 0.9 \\
\quad(0.25 \pm 0.02) \mathrm{a}\end{array}$ & $\begin{array}{l}28.0 \pm 1.3 \\
\quad(0.65 \pm 0.03) \mathrm{a}\end{array}$ & $\begin{array}{l}43.1 \pm 0.1 \\
\quad(1)\end{array}$ \\
\hline BB22 & $\begin{array}{l}30.2 \pm 0.4 \\
\quad(0.73 \pm 0.02) \mathrm{b}\end{array}$ & $\begin{array}{l}40.9 \pm 0.5 \\
\quad(0.99 \pm 0.02) b\end{array}$ & $\begin{array}{l}13.7 \pm 1.2 \\
\quad(0.33 \pm 0.03) \mathrm{a}\end{array}$ & $\begin{array}{l}38.9 \pm 0.5 \\
\quad(0.94 \pm 0.01) \mathrm{a}\end{array}$ & 0 & $\begin{array}{l}15.0 \pm 0.6 \\
\quad(0.36 \pm 0.02) b\end{array}$ & $\begin{array}{l}14.0 \pm 0.6 \\
\quad(0.34 \pm 0.02) \mathrm{b}\end{array}$ & $\begin{array}{l}41.6 \pm 0.6 \\
\text { (1) }\end{array}$ \\
\hline BB24 & $\begin{array}{l}27.1 \pm 0.3 \\
\quad(0.72 \pm 0.01) \mathrm{b} \\
F_{2,24}=588.3\end{array}$ & $\begin{array}{l}32.6 \pm 0.5 \\
\quad(0.87 \pm 0.02) \mathrm{c} \\
F_{2,24}=81.0\end{array}$ & $\begin{array}{l}20.7 \pm 0.6 \\
\quad(0.55 \pm 0.01) \mathrm{b} \\
F_{2,24}=26.7\end{array}$ & $\begin{array}{l}33.8 \pm 0.7 \\
\quad(0.90 \pm 0.02) \mathrm{a} \\
F_{2,24}=1.6\end{array}$ & 0 & $\begin{array}{l}9.7 \pm 0.6 \\
\quad(0.26 \pm 0.01) \mathrm{a} \\
F_{2,24}=11.0\end{array}$ & $\begin{array}{l}12.9 \pm 0.7 \\
\quad(0.35 \pm 0.02) \mathrm{b} \\
F_{2,24}=60.6\end{array}$ & $\begin{array}{l}37.6 \pm 0.2 \\
\text { (1) }\end{array}$ \\
\hline
\end{tabular}

${ }^{\text {a }}$ Colony diameter on fungicide/colony diameter on control for each replicate; $F$ values (ANOVA) are indicated for each column; mean GRs within a column followed by different lowercase letters are significantly different $(p<0.05$, Tukey's HSD tests) 


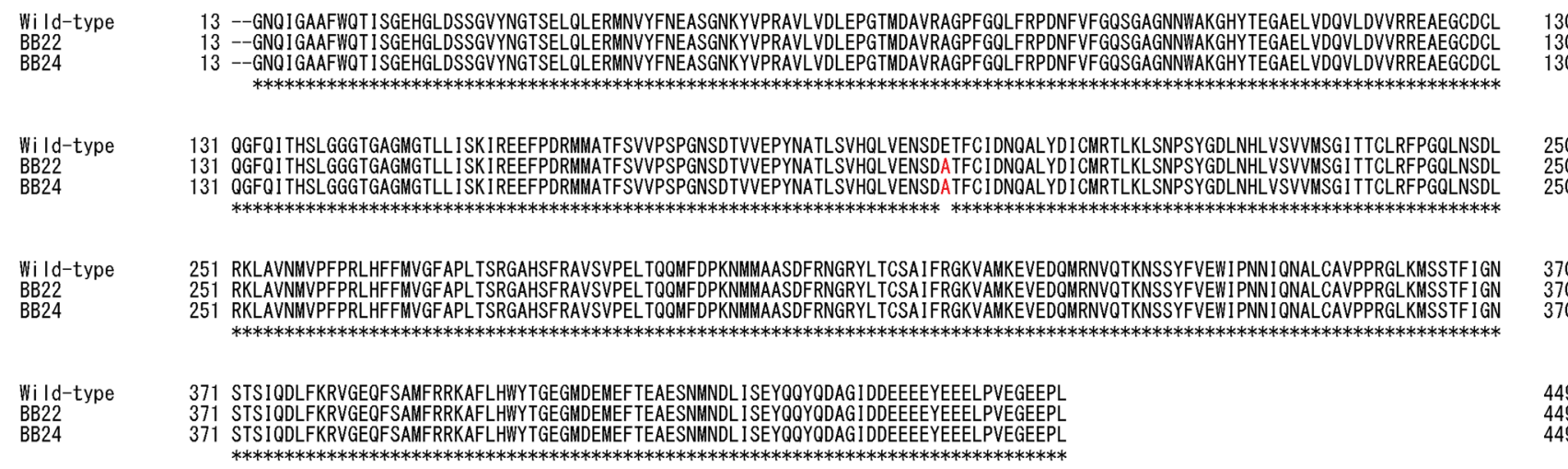

Fig. 2 Multiple alignment of the deduced amino acid sequence of $\beta$-tubulin in wild and mutant isolates of B. bassiana by CLUSTAL W (Thompson et al. 1994). Numbers on the left and right indicate sequence positions. Asterisks indicate amino acids conserved in all isolates

(Keinath and Zitter 1998). Interestingly, the mutant isolates were also significantly more tolerant to triflumizole (only BB22) and iprodione (only BB24) than the wild isolate $(p<0.05$, Tukey's HSD test), suggesting that the mutant isolates may have multiple mechanisms conferring tolerance to other fungicides that are not benzimidazoles.

In contrast, on diethofencarb, both BB22 and BB24 had significantly smaller GRs ( 0.34 and 0.35 , respectively) than the wild isolate (GR: 0.65) $(p<0.05$, Tukey's HSD test) and were therefore more sensitive than the wild isolate to this chemical. This increased sensitivity may result from negative cross-resistance between benzimidazole fungicides and $N$-phenylcarbamate fungicides, such as diethofencarb (Fujimura et al. 1992; Ziogas and Girgis 1993). Overall, fungicides indicating positive or negative cross-resistance in the present study were similar to fungicides in our recent observations for ion beam irradiation-induced benomyl-resistant mutants of I. fumosorosea (Shinohara et al. 2013).

The $\beta$-tubulin loci of wild and mutant isolates were sequenced to identify mutation sites. Two partial genomic DNA sequences of 1,428 bp (positions 303 to 1,730 ) were characterized for all isolates. Isolates BB22 and BB24 both had a single mutation at position $924($ A:T $\rightarrow$ C:G), which caused an amino acid replacement at position 198 $(\mathrm{E} \rightarrow \mathrm{A}$ ) (Fig. 2). The $\beta$-tubulin sequences of the wild isolate and mutant isolates (BB22 and BB24) have been assigned in the DDBJ/EMBL/GenBank with accession nos. AB830334, AB829898 and AB829899, respectively.

Benzimidazole fungicides bind to $\beta$-tubulin in the microtubules, thereby inhibiting their proliferation and suppressing dynamic instability (Davidse 1986; Koo et al. 2009). In fact, many mutation sites at the $\beta$-tubulin locus have been found in benzimidazole-resistant plant-pathogenic fungi (e.g., Albertini et al. 1999; Qiu et al. 2011), but most molecular studies have focused on replacement of the amino acid at position 198 and/or 200 (e.g., Davidson et al. 2006; Fujimura et al. 1992; Hollomon et al. 1998).
Mutation at position 198 in particular resulted in resistance to benzimidazole fungicides in the plant-pathogenic fungi Monilinia fructicola (G. Winter) Honey (Ma et al. 2003) and Venturia inaequalis (Cooke) G. Winter (Koenraadt et al. 1992). In previous studies on the entomopathogenic fungus $B$. bassiana, mutation at position 198 also led to resistance to benzimidazoles when glutamate was replaced with lysine (E198 K), glycine (E198G) or valine (E198V) (Butters et al. 2003; Zou et al. 2006). In our study we also found a mutation at position 198 in both mutant isolates, suggesting that mutations at this position are also very important in $B$. bassiana. However, in our study the glutamate was replaced with alanine (E198A). The potential mechanisms for benomyl-resistance may be different between B. bassiana and I. fumosorosea, because no mutation at position 198 of the $\beta$-tubulin locus was detected in benomyl-resistant I. fumosorosea mutants produced by ionbeam irradiation (Shinohara et al. 2013).

In conclusion, this study indicates that ion beams are useful tools for enhancing fungicide resistance in $B$. bassi$a n a$, as has previously been shown for I. fumosorosea (Shinohara et al. 2013). Fungicide-resistant mutants produced in this way could be useful agents for biological control within IPM programs using fungicides, once they have been evaluated for other important characteristics, particularly virulence to target insects.

Acknowledgments We thank Prof. I. Uwafuji for helpful advice on statistical analyses. We thank J. K. Pell Consulting for editing of the manuscript. This work was supported financially by JSPS KAKENHI grant no. 24510121 and by the program of the Directorate General of Higher Education of Indonesia.

\section{References}

Abbott WS (1925) A method of computing the effectiveness of an insecticide. J Econ Entmol 18:265-267 
Albertini C, Gredt M, Leroux P (1999) Mutations of the $\beta$-tubulin gene associated with different phenotypes of benzimidazole resistance in the cereal eyespot fungi Tapesia yallundae and Tapesia acuformis. Pestic Biochem Physiol 64:17-31

Boucias DG, Pendland JC (1998) Principles of insect pathology. Kluwer Academic Publishers, London

Butters JA, Devi KU, Mohan CM, Sridevi V (2003) Screening for tolerance to bavistin, a benzimidazole fungicide containing methyl benzimidazol-2-yl carbamate (MBC), in Beauveria bassiana: sequence analysis of $\beta$-tubulin gene to identify mutations conferring tolerance. Mycol Res 107:260-266

Clark RA, Casagrande RA, Wallace DB (1982) Influence of pesticides on Beauveria bassiana, a pathogen of the Colorado potato beetle. Environ Entomol 11:67-70

Copping LG (2009) The manual of biological agents, 4th edn. BCPC, Hampshire

D’Alessandro CP, Padin S, Urrutia MI, López Lastra CC (2011) Interaction of fungicides with the entomopathogenic fungus Isaria fumosorosea. Biocontrol Sci Techn 21:189-197

Das SK, Masuda M, Hatashita M, Sakurai A, Sakakibara M (2008) A new approach for improving cordycepin productivity in surface liquid culture of Cordyceps militaris using high-energy ion beam irradiation. Lett Appl Microbiol 47:534-538

Davidse LC (1986) Benzimidazole fungicides: mechanism of action and biological impact. Annu Rev Phytopathol 24:43-65

Davidson RM, Hanson LE, Franc GD, Panella L (2006) Analysis of $\beta$-tubulin gene fragments from benzimidazole-sensitive and -tolerant Cercospora beticola. J Phytopathol 154:321-328

Fujimura M, Oeda K, Inoue H, Kato T (1992) A single amino-acid substitution in the beta-tubulin gene of Neurospora confers both carbendazim resistance and diethofencarb sensitivity. Curr Genet 21:399-404

Goettel MS, Inglis GD (1997) Fungi: Hyphomycetes. In: Lancey LA (ed) Manual of techniques in insect pathology. Academic Press, London, pp 213-249

Hollomon DW, Jenny A, Butters JA, Barker H, Hall L (1998) Fungal $\beta$-tubulin, expressed as a fusion protein, binds benzimidazole and phenylcarbamate fungicides. Antimicrob Agents Chemother 42:2171-2173

Inglis GD, Goettel MS, Butt TM, Strasser H (2001) Use of Hyphomycetous fungi for managing insect pests. In: Butt TM, Jackson C, Magan N (eds) Fungi as biological control agents: progress, problems and potential. CABI Publishing, Oxon, pp 23-69

James RR, Croft BA, Shaffer BT, Lighthart B (1998) Impact of temperature and humidity on host-pathogen interactions between Beauveria bassiana and a coccinellid. Biol Control 27:1506-1513

Keinath AP, Zitter TA (1998) Resistance to benomyl and thiophanatemethyl in Didymella bryoniae from South Carolina and New York. Plant Dis 82:479-484

Kim SK, Shim HJ, Roh JY, Jin BR, Boo KS, Je YH (2005) Isolation and characterization of benomyl-resistant mutants in an entomopathogenic fungus, Metarhizium anisopliae. Int J Indust Entomol 10:119-123
Koenraadt H, Somerville SC, Jones AL (1992) Characterization of mutations in the beta-tubulin gene of benomyl-resistant field strains of Venturia inaequalis and other plant pathogenic fungi. Phytopathology 82:1348-1354

Koo BS, Park H, Kalme S, Park HY, Han JW, Yeo YS, Yoon SH, Kim SJ, Lee CM, Yoon MY (2009) $\alpha$ - and $\beta$-tubulin from Phytophthora capsici KACC 40483: molecular cloning, biochemical characterization, and antimicrotubule screening. Appl Microbiol Biotechnol 82:513-524

Ma Z, Yoshimura MA, Michailides TJ (2003) Identification and characterization of benzimidazole resistance in Monilinia fructicola from stone fruit orchards in California. Appl Environ Microbiol 69:7145-7152

Matuo Y, Nishijima S, Hase Y, Sakamoto A, Tanaka A, Shimizu K (2006) Specificity of mutations induced by carbon ions in budding yeast Saccharomyces cerevisiae. Mutat Res 602:7-13

Qiu J, Xu J, Yu J, Bi C, Chen C, Zhou M (2011) Localisation of the benzimidazole fungicide binding site of Gibberella zeae $\beta 2$-tubulin studied by site-directed mutagenesis. Pest Manag Sci 67:191-198

Saito T (1984) Effect of pesticides on conidial germination and hyphal growth of the entomopathogenic fungus Beauveria bassiana. Jpn J Appl Entomol Zool 28:87-89 (in Japanese with English summary)

Shinohara S, Fitriana Y, Satoh K, Narumi I, Saito T (2013) Enhanced fungicide resistance in Isaria fumosorosea following ionizing radiation-induced mutagenesis. FEMS Microbiol Lett 349:54-60

SPSS (2009) PASW statistics 18. SPSS Inc., Chicago

Tanaka A, Shikazono N, Hase Y (2010) Studies on biological effects of ion beams on lethality, molecular nature of mutation, mutation rate, and spectrum of mutation phenotype for mutation breeding in higher plants. J Radiat Res 51:223-233

Thompson JD, Higgins DG, Gibson TJ (1994) CLUSTAL W: improving the sensitivity of progressive multiple sequence alignment through sequence weighting, position-specific gap penalties and weight matrix choice. Nucleic Acids Res 22:4673-4680

Toyoshima Y, Takahashi A, Tanaka H, Watanabe J, Mogi Y, Yamazaki T, Hamada R, Iwashita K, Satoh K, Narumi I (2012) Lethal and mutagenic effects of ion beams and $\gamma$-rays in Aspergillus oryzae. Mutat Res 740:43-49

Valadares-Inglis MC, Inglis PW (1997) Transformation of the entomopathogenic fungus, Metarhizium flavoviride strain CG423 to benomyl resistance. FEMS Microbiol Lett 155:199-202

Ziogas BN, Girgis SM (1993) Cross-resistance relationships between benzimidazole fungicides and diethofencarb in Botrytis cinerea and their genetical basis in Ustilago maydis. Pestic Sci 39:199-205

Zou G, Ying SH, Shen ZC, Feng MG (2006) Multi-sited mutations of $\beta$-tubulin are involved in benzimidazole resistance and thermotolerance of fungal biocontrol agent Beauveria bassiana. Environ Microbiol 8:2096-2105 